\title{
Promoting sustainability education through hands-on approaches: a tree carbon sequestration exercise in a Singapore green space
}

\author{
Sorain J. Ramchunder ${ }^{1}$ (D) Alan D. Ziegler ${ }^{2}$
}

Received: 3 August 2020 / Accepted: 9 December 2020 / Published online: 16 January 2021

(c) The Author(s), under exclusive licence to Springer Japan KK part of Springer Nature 2021

\begin{abstract}
During a university class project related to climate change mitigation strategies, we utilized a university green space as a "living laboratory" for collaborative learning exercise to estimate landscape-level carbon biomass storage. The key objective of the exercise was to foster sustainability awareness with regard to the effectiveness of tree-planting initiatives to offset carbon emissions. Collaborative learning is a process by which students work together in small groups to accomplish a common goal. As experiences are active, social and student-owned, the process leads to the development of a variety of cognitive and transferable skills that are beneficial in academia and the workplace. Through data collection/analysis, the carbon biomass exercise not only allowed students to assess critically the efficacy of a tree-planting initiative as a means to sequester carbon, but they became aware of the difficulties in performing research on complex environmental issues. The intention of the research was to give students an opportunity to practice data collection, data analysis, problem solving, teamwork, communication and scientific literacy skills, meanwhile utilizing the campus open green space to enhance the knowledge discovery process. Informal assessment and discussions with students demonstrated that the activity was successful in reaching a wide range of students with varying backgrounds and initial attitudes about climate change mitigating strategies, which was our objective. Our case study demonstrates how learning objectives can be integrated with university sustainability initiatives to improve learning and student engagement. Finally, we see green spaces as dynamic settings for learning about physical processes and issues related to environmental management and sustainability.
\end{abstract}

Keywords Tree carbon biomass assessment $\cdot$ Allometry $\cdot$ Sustainability education $\cdot$ Environmental science $\cdot$ Singapore carbon footprint

\section{Introduction}

Sustainability teachers in higher education generally agree that the purpose of the topic is fostering agents of change (students) who will someday be capable of tackling complex and intertwined challenges related to sustainability (Jones et al. 2010). However, traditional classroom approaches

Handled by Mekuria Argaw, Addis Ababa University College of Natural Sciences Center for Environmental Science Arat Kilo Addis Ababa, Ethiopia.

Sorain J. Ramchunder

geosjr@nus.edu.sg

1 Department of Geography and Bachelor of Environmental Studies, National University of Singapore, Singapore, Singapore

2 Faculty of Fisheries Technology and Aquatic Resources, Mae Jo University, Chiang Mai, Thailand to sustainability education that generally focus on content alone may not be the most effective method, as they force students to be passive recipients of information, rather than active learners in a manner more in the spirit of solving environmental problems (Blumstein and Saylan 2007; DuPuis and Ball 2013). The combined application of active, participatory and experiential learning, grounded in a specific environmental context allows students to examine processes instead of purely memorizing their characteristics and in turn develop meaningful relationships with the environment they live in (cf. Burns 2015). To accomplish these goals, the students need to be engaging with the outdoors on occasion.

Urban green spaces have great potential as outdoor learning spaces for some issues related to sustainable development, which succinctly refers to utilizing our natural capital in a manner that fosters economic growth, preserves environmental integrity, and promotes social well-being, but does not reduce the capacity of future generations to also flourish 
similarly (Brundtland 1987). With respect to health, green spaces stimulate mental and physical health by providing venues for psychological relaxation and stress alleviation, stimulating social cohesion, and supporting physical activities that reduce morbidity (Fuller et al. 2007; Braubach et al. 2017). From an environmental perspective, green space infrastructure within a built environment reduces exposure to air, water and noise pollutions (e.g., Jim and Chen 2008), decreases surface water runoff (e.g., Whitford 2001), provides habitat for flora and fauna (e.g., Gehrt and Chelsvig 2004), mitigates urban heat (e.g., Wong and Chen 2008), and promotes the accumulation of vegetation biomass, and therefore, carbon (Trlica et al. 2020). Due to this diversity of services, green spaces should, therefore, be useful for supporting activities related to sustainability education, which seeks to instil values and motivate students to actively promote sustainability (Martins et al. 2006; Wolsink 2016).

One important sustainability issue on the minds of many students relates to their carbon footprint, or that of his/ her city or nation. In recognition that one tree can intake as much as one megagram $(\mathrm{Mg})$ of carbon dioxide in its lifetime (40-100 + years; European Environment Agency 2012) and serve as filters for urban pollutants including fine particulates, a number of cities are now making concerted efforts to improve green spaces by boosting the number of trees via greening initiatives (City of New York 2011; City of London 2020; Frangoul 2020). Singapore is recognized as being on the forefront of urban greening among global cities (Newman 2014). The $722 \mathrm{~km}^{2}$ island nation plans to plant one million trees by 2030, transforming it into a 'City in Nature' (National Parks Board 2020). One focus area for planting is the National University of Singapore (NUS), where the Planting 10,000 Trees initiative began in November 2018 with a goal to foster cognitive and emotive well-being, and promote social interactions (National University of Singapore 2018). This 3-year Campus Greenery Plan, which aims to plant 500 mature and 9,500 saplings throughout the campus, aspires to preserve Singapore's biodiversity, mitigate climate change (via carbon sequestration) and become a recognized environmentally responsible campus (National University of Singapore 2018). With respect to the urban heat island effect (Arnfield 2003), the shading of heat-absorbing surfaces by the newly planted trees is expected to cool down surrounding temperatures by about one degree Celsius (National University of Singapore 2018) and reduce thermal discomfort (Chow et al. 2016). Further, the trees have the potential to sequester about $220 \mathrm{Mg}$ of carbon annually (National University of Singapore 2018). Like many universities worldwide, NUS is showing a novel commitment to sustainability and biophilia that is evident in campus planning to integrate built and open spaces with green infrastructure (Way et al. 2012; Painter et al. 2013; Kellert and Calabrese 2015).
One potentially overlooked benefit of the university campus-greening initiative is the potential roles for green spaces as educational resources. Historically, the place where faculty and students come together for formal learning is the classroom (cf. Bonwell and Sutherland 1996). However, new methods of teaching based on an improved understanding of cognition have emerged, promoting the evolution of what places/spaces/situations are considered a classroom: the classroom is no longer defined by "the class" per se, but by the "learning" achieved (Oblinger 2005). While many universities have invested in building formal learning spaces (e.g., classroom, discussion rooms, study lounge areas and libraries), the entire campus, including its open spaces (informal learning spaces) is arguably part of a holistic learning space (Painter et al. 2013; Scholl and Gulwadi 2015). Furthermore, in an attempt to informalize learning, universities have renovated learning spaces within buildings, employed flexible furniture arrangements, and increased the use of information technology in student learning all in an effort to foster an active and student-led learning experience (Monahan 2002; Oblinger 2005; Blackmore et al. 2011; Byers et al. 2014).

Prior research has focused on libraries, gathering spaces, and in-between spaces such as the areas within corridors and lobbies (Fig. 1). In addition, on-campus or nearby green spaces are potentially rewarding spaces for teaching a variety of cross-disciplinary topics (Wolsink 2016): e.g., those associated with the environment and sustainability (e.g., natural resource management, ecology, forestry and environmental management). In contrast to a lecture hall, an open green space provides phenomena (e.g., plants; temperature; wind) that are linked to processes (e.g., carbon sequestration; evapotranspiration) that can be studied directly and in situ, thereby reinforcing the learning process by substituting abstraction with realism. Use of green spaces creates an opportunity to augment the traditional classroom-based lecturing approach, or teacher-centered approach (Bonwell and Sutherland 1996), by allowing students to learn in alternative, dynamic, and less sterile spaces, for example, via collaborative learning.

Collaborative learning is a student-centric approach involving groups working towards a common academic goal in a situation where the instructor's role is diminished in the traditional sense. The learning space is, therefore, not necessarily fixed or formal, and the student's role takes center stage (cf. Gokhale 1995). The instructor is more so a facilitator of learning than a person regurgitating information. An example of collaborative learning related to sustainability education might involve group-based fieldwork designed to help students increase their knowledge of a particular environmental issue by attempting to solve one aspect of the problem by putting theory to practice. One such example, which is the focus of this paper, is investigating the role of 


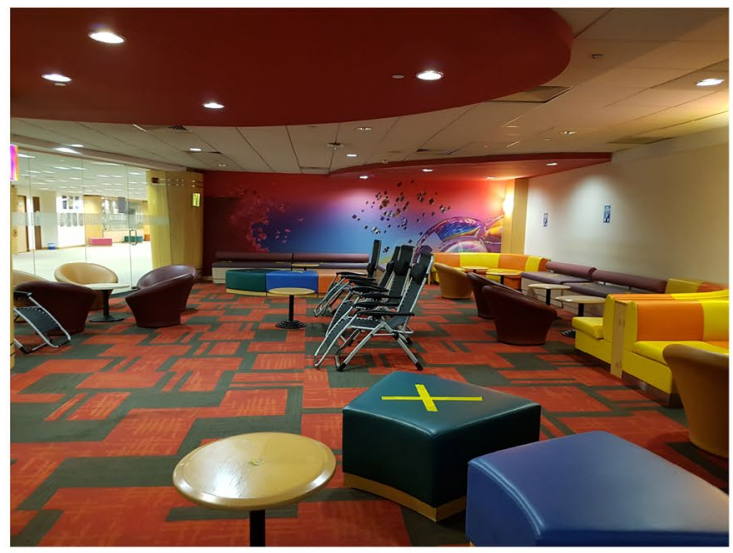

Library: Computer banks, alcoves (these space have been modified or deliberately designed to foster collaboration and a communal learrning enviornment)

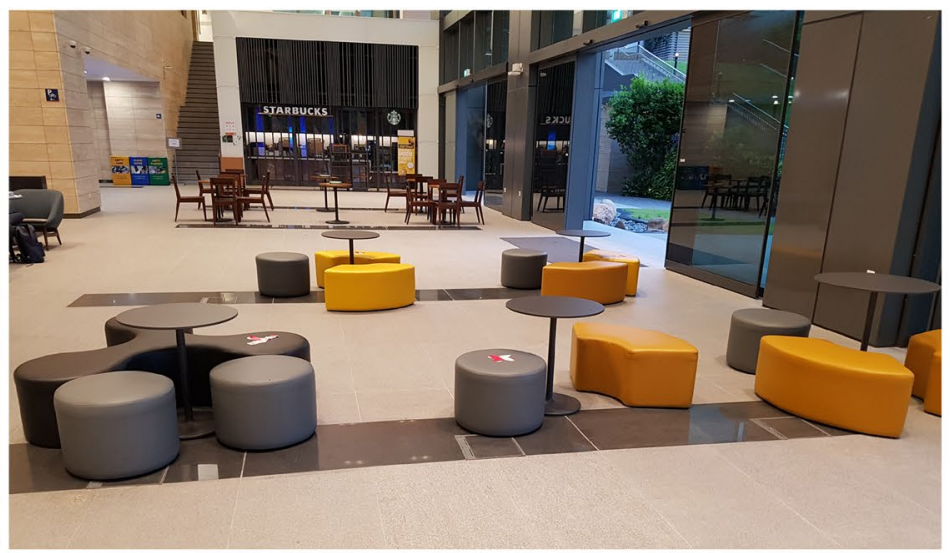

Gathering spaces: Food service areas, student unions, student centers and outdoor spaces. These spaces are typically designed for academic. social and personal purposes such as discussing studies over food or drinks

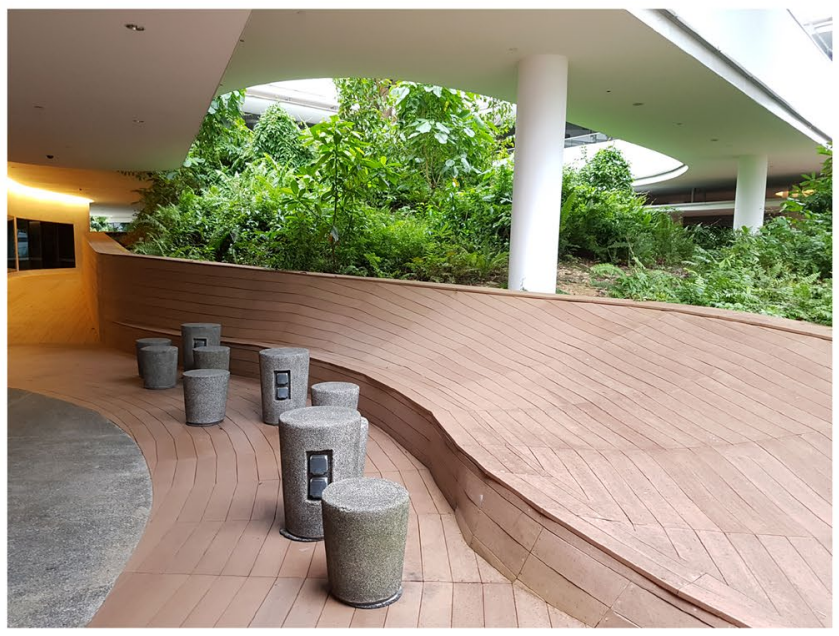

Transitional Spaces: Lobbies, corridors and courtyards connecting classrooms and offices. These spaces may be furnished to accommodate informal learning activities

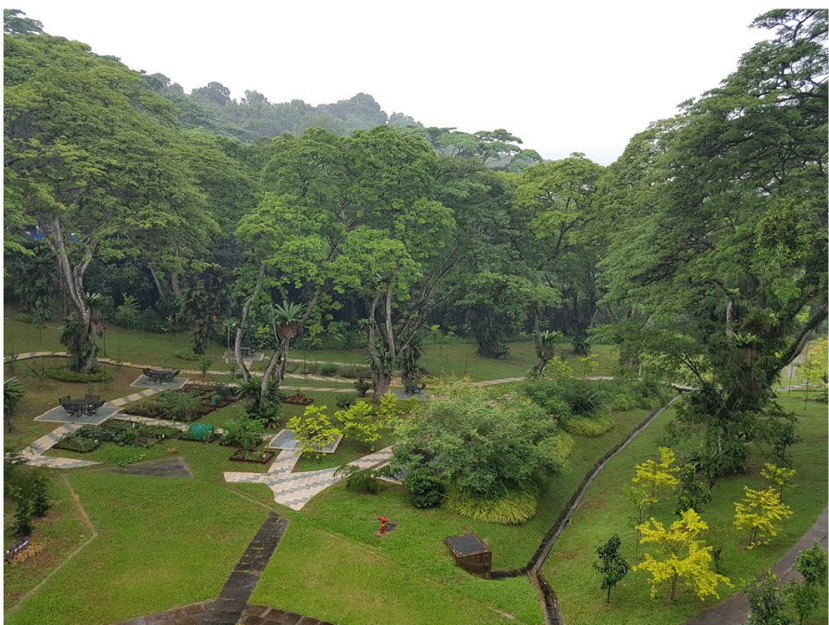

Outdoor green spaces: Forest, stream, lake, lawn and garden

Fig. 1 Informal campus learning spaces at NUS (types adapted from Painter et al. 2013)

carbon biomass sequestration as a strategy for mitigating climate change impacts. This issue often strikes a chord with students because of the considerable carbon footprint of universities and the cities in which they are usually located. The growing pressures to reduce anthropogenic carbon emissions in the pursuit of living sustainably in the future is a goal that many environmentally minded students share. Yet, many students are unaware of their own carbon footprint, and few have a strong understanding of the science foundations of proposed carbon management initiatives to offset climate change.

Teaching about the linkage between climate and sustainability is challenging when students have widely diverging views regarding the reality/severity of climate change, its underlying cause, the effectiveness of potential mitigation measures, and the role they as a citizen can play in mitigating its impacts. Many of these issues are complicated by the following: (a) poor communication, including the jargon of 
science and academic discourse; (b) incomplete knowledge of physical processes, complex systems, and uncertainty, difficulties with interdisciplinary communication, and (c) poor leadership as reflected in the reluctance of governments to recognize the need to act now (Robinson 2011). Further, public skepticism and uncertainty may stem from a variety of sources including model-based uncertainty and probabilities, expert disagreements, misleading sources of information (e.g., media, politicians, campaign groups), political agendas, and individual differences in beliefs and values (Patt 2007; Kahan et al. 2011; Whitmarsh 2011). From an education perspective, learning may also be hindered by a method of teaching that fails to engage students, or fails to make them essential actors in the learning process.

In this paper, we describe a campus-based collaborative learning exercise in 2019 focused on estimating landscapelevel carbon biomass storage on a green space in the NUS campus, the site of the Planting 10,000 Trees initiative (Fig. 2). The objective was to develop self-awareness in the students about their carbon footprint, as well as the effectiveness of tree planting to offset carbon emissions. The exercise was also designed to provide opportunities for students to develop transferable skills and attain knowledge relevant to employment in the environmental and sustainability sector. Inherent in the exercise is addressing uncertainty, a topic we recognize that many students find confusing and difficult. Typically, students are introduced to uncertainty in STEM subjects, for example during laboratory work (Duerdoth 2009). Thus, the campus-based exercise provides an informal approach to teaching and discussing uncertainty in a means that is conceptually simple and attractive to general environmental studies' students.
This paper introduces the exercise, describes the learning process (including skills acquired), and discusses the wider implications of using green spaces on university campuses for educational purposes. Our motivation for this paper is to share our experience and to promote out-of-classroom experiential learning. Our intention is for the paper to be more of a discussion, but we do provide an informal hypothesisbased test using students from two separate modules: (1) Control, for which students are exposed to environmental issues, but carbon management is not a key component; and (2) Test, for which the students were exposed to carbon management through the exercise presented in this paper. Our hypothesis was that the Test class would have a different perspective regarding the viability of tree planting for carbon sequestration because they performed an assessment of carbon storage.

\section{Carbon biomass exercise}

In brief, the exercise involved using allometry to determine the carbon biomass in the mature trees within a 1-ha wooded green space that was adjacent to the building where the students attended class (see below for additional details).

\section{Carbon balance and climate change}

With increasing concern about greenhouse gas-driven climate change, attention has turned towards developing and/ or enhancing existing carbon capture and storage (CCS) technologies, such as injecting carbon dioxide into stable geological formations and tree-planting initiatives (see
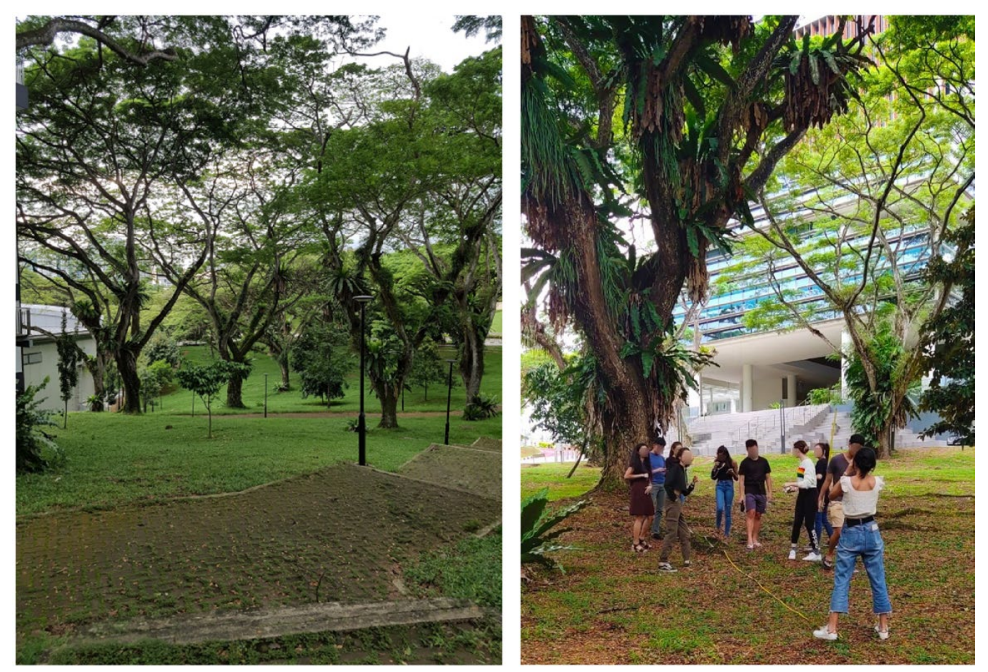

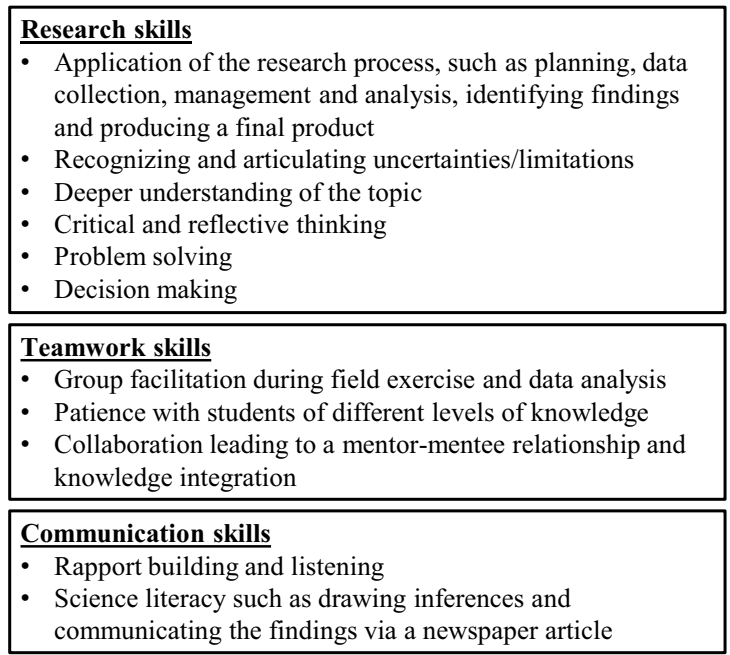

Fig. 2 (Left) The studied forested green space on the NUS campus; (center) Two groups of five students working collaboratively during the carbon assessment exercise. Photos have been blurred to protect student identity; (right) Outcome of skills gained from the collaborative learning exercise 
Raza et al. 2019 for a full review on CCS). While the feasibility of the former is still being researched, tree-planting initiatives are being implemented worldwide at a variety of scales (Pandey 2019). Some see forest restoration as a "mechanism to achieve multiple goals, including climate mitigation, biodiversity conservation, socioeconomic benefits, food security, and ecosystem services" (cf. Bastin et al. 2019; Chazdon and Brancalion 2019). However, a central critique is that tree-planting initiatives, even at large scales, represent a short-term solution for which estimates of carbon sequestration/storage rates are uncertain (Popkin 2019; Holl and Brancalion 2020).

Indeed, a paper published in Nature suggested that while trees are supposed to slow global warming via $\mathrm{CO}_{2}$ removal from the atmosphere, growing evidence suggests they might not be "climate saviours" (Popkin 2019). Skepticism revolves around the uncertainty in determining how much carbon is "locked up" by trees, which fundamentally is a balance between how much they remove from the air for photosynthesis and wood production and that which they release through respiration and decay (Pan et al. 2011; Popkin 2019). In a recent study, Lewis et al. (2019) estimated a carbon storage increase of 42 billion $\mathrm{Mg}$ if the Bonn Challenge restored 3.5 million square kilometers of natural forest by 2100 through reforestation. Alternatively, only one billion $\mathrm{Mg}$ of carbon would be sequestered if the same area was exclusively used for plantations (Lewis et al. 2019). Such divergence in estimates in carbon storage again related to inherent uncertainties associated with differences in tree species growth rates, spacing, maintenance, climate, and the life-stage of the tree (Chen et al. 2017). The main aspect of uncertainty that we are addressing in this paper is associated with carbon biomass storage estimates based on the use of allometric equations.

\section{Allometry}

A common method for determining the carbon biomass of plants is to destructively harvest the above-and belowground components including stems, branches, leaves, flowers, fruits and roots (Roxburgh et al. 2015). From these components, allometric relationships are developed using the respective masses (often total mass) and easily measured aspects of tree physiology such as trunk diameter, tree height, wood density (Yuen et al. 2016). Allometry is a fundamental biological principal that was conceived as the study of how the physiology of an organism changes with size-related traits (Huxley 1932), for example via power-law relationships of the following form:

$\mathrm{Y}=\mathrm{a} \mathrm{X}^{\mathrm{b}}$ where $Y$ and $X$ are the related variables, $a$ is the normalization constant, and $b$ is the exponent (Sileshi 2014; Yuen et al. 2016). Metabolic theory is found on evidence that a many biological properties scale with body size via a power-law relationship over many orders of magnitude (Brown et al. 2004). Within forestry, the power-law is a common form for allometric equations used to calculate biomass (Banaticla et al. 2007; Chan et al. 2013).

Problematic in developing allometric equations is the uncertainty in the equation itself, which is based on regression performed on data often collected from a limited number of trees in a specific site (Clark and Kellner 2012). Datasets are often small because sampling is time consuming, costly, and destructive. Further, individual biomass variability for a particular species can be great. Thus, Eq. (1) can be rewritten as:

$\mathrm{Y}=\mathrm{a} \mathrm{X}^{\mathrm{b}}+\xi$

where $\xi$ represents the error or uncertainty term associated with the regression or measurement errors (Cunia 1987; Muller-Landau et al. 2014; Cushman et al. 2014). Typically, $\xi$ is ignored in practice, but one should be aware of its magnitude.

These days, the establishment of an allometric relationship at individual sites is usually not performed, as destructive sampling goes against conservation objectives in most managed systems in the world (Brown 2002). An alternative approach is to use published allometric equations to estimate biomass. These relationships are based on destructive sampling performed in the past or in areas where tree felling is permitted (Roxburgh et al. 2015). Most carbon biomass assessments worldwide now rely heavily on these "proxy" allometric relationships (Shi and Liu 2017). A recent review of allometric equations for tropical land-cover biomass is provided by Yuen et al. (2016). Errors associated with using proxy allometric equations stem from the equation not representing site-specific growing conditions (e.g., moisture regime, soil, and altitude) or disturbance regime (Laurance et al. 1999; Fisher et al. 2008; Heryati et al. 2011). In addition, the vegetation in question may not have a proxy equation. In the latter case, an equation of a species with similar life form must be borrowed, or a broad-based equation based on forest type must be used. The latter case is specific to the exercise we introduced to the students.

\section{Field measurements and allometry calculations}

Students were assigned the task of estimating the total tree carbon biomass in a 1-ha green space containing 23 established (approximately 40-years-old) rain trees (Samanea saman) and 39 newly planted trees of a variety of species (e.g., Sterculia parviflora, Garcinia hombroniana, G. cowa 
and Maniltoa browneoides). The site was selected because of its convenience of access and proximity to the classroom allowing the exercise to take place during normal class hours (Fig. 2). The is representative of other wooded green spaces on campus and throughout Singapore.

The students worked in small groups to facilitate collecting the measurements, and they were required to participate in all measurements (observation only was discouraged). During measurement, students were asked to take copious notes, and pay particular attention to the "state" of the trees and potential sources of measurement error. Back in the classroom, the data were collated to produce Excel (or $\mathrm{R})$ graphs and tables containing pertinent information on carbon storage at the site. Following field measurements, the students were assigned to compute AGCB and BGCB for the plot, then write a newspaper article that relays the implications of the tree-planting initiative to the public in non-technical terms.

Above-ground (AGB) and below-ground (BGB) biomass were determined from the following two equations from Chave et al. (2014) and Yuen et al. (2013), respectively, for tropical forests:

$\mathrm{AGB}=0.0673\left(p \mathrm{D}^{2} \mathrm{H}\right)^{0.976}$

$\mathrm{BGB}=0.18 * \mathrm{AGB}$

where $\mathrm{D}$ is the diameter of tree trunks at breast height $(\mathrm{cm})$, or $1.3 \mathrm{~m}$ from the ground; $\mathrm{H}$ is tree height $(\mathrm{m})$; and $p$ is wood density $\left(\mathrm{g} / \mathrm{cm}^{-3}\right)$. We used $p$ values of 0.450 for rain trees and 0.534 for all other trees (IPCC 2006). Tree diameter was estimated with a diameter tape. Tree height was determined as $\mathrm{H}=\mathrm{L} \times \tan (\Theta)$, where $\mathrm{L}$ is distance from the operator to a tree; and $\Theta$ is the angle $\left({ }^{\circ}\right)$ from the operator to the top of the tree, determined from a laser hypsometer (Fig. 2). Equations 3 and 4 are chosen for their simplicity and applicability to the Singapore setting where no location-specific equations have been established. Other equations could be substituted depending on the locale. Equation 3 is a pantropical model determined by Chave et al. (2014) for numerous tropical sites worldwide. Equation 4 is from the meta-analysis by Yuen et al. (2013) for available data in SE Asia allowing calculation of root:shoot ratios. Note that the error term $(\xi)$ from Eq. 2 has been omitted, as is typically done in practical usage.

In the exercise, above-ground (AGCB) and below-ground (BGCB) carbon biomass were estimated by assuming it is one-half of the AGB and BGB values (Matthews 1993; Brown 1997). Ideally, we should have sampled the trees with a tree borer to determine the carbon values, but this was not allowed by campus facility managers for fear of introducing a disease vector to the trees. The mass of the $\mathrm{CO}_{2}$ equivalents $\left(\mathrm{CO}_{2} \mathrm{eq}\right)$ stored in a tree can be determined by multiplying the carbon mass by a stoichiometric conversion factor of 3.67, which is the ratio of the molecular weight of carbon dioxide to carbon (44/12) (IPCC 2003; Petersson et al. 2012). The unit of presentation of carbon mass was $\mathrm{Mg}$ (Megagram, or one metric tonne).

\section{Motivation}

Motivation for the exercise stems from the advanced level (4th year) of the course and the composition of both geography and environmental science students. Lecture time is typically used to explain the theory of each topic and to give relevant examples with follow on discussions on assigned readings, but has limited field-based teaching to explore contemporary scientific approaches. In Geography/Environmental Sciences, field exercises are central in relating theory to practice and placing students in settings to develop analytical, observational and technological skills (Fuller 2006). Small groups were chosen specifically to facilitate collaboration by all students (Schellens and Valcke 2006). With respect to module composition, collaborative learning with students from different disciplines can stimulate the students to understand different levels of thinking (Gokhale 1995), and to practice transdisciplinary research (Ziegler et al. 2016).

Our intention with the assessment was twofold: (1) to educate future environmental science professionals in developing and improving effective environmental science literacy and communication skills; and (2) to provide an alternative form of assessment that reflects the nature of an inquiry-oriented discipline present in Environmental Sciences. This gave the students an opportunity to communicate more than the basic knowledge of science facts or contemporary definitions in carbon management, but also include the scientific processes and practices to encourage scientific inquiry within the reader (Yarnal and Neff 2007). Related, we wanted to encourage higher-order skill of critical thinking by synthesizing information and applying factual knowledge and concepts to complex, real-world situations.

\section{The learning process}

\section{Outcomes}

In brief, the students learned that the measured DBHs were significantly different for rain trees (mean \pm stdev $=$ $99 \pm 22 \mathrm{~cm}$; range $=56-154 \mathrm{~cm}$ ) compared with the other trees in the plot $(10 \pm 4 \mathrm{~cm} ; 4-19 \mathrm{~cm})$. The corresponding mean heights were also significantly different: $16 \pm 3 \mathrm{~m}$ $(10-21 \mathrm{~m})$ versus $6 \pm 2 \mathrm{~m}(2-12 \mathrm{~m})$. Total AGCB and BGCB estimates for the plot were 53 and $10 \mathrm{Mg} \mathrm{C}$, respectively. Of the total carbon biomass (63 Mg C; equivalent to 
$231 \mathrm{Mg} \mathrm{CO}_{2}$ eq), nearly all $\left(62 \mathrm{Mg} ; 231 \mathrm{Mg} \mathrm{CO}_{2}\right.$ eq) was associated with the 23 mature rain trees (assuming they are 40 years old). The mean carbon content of each rain tree was $2.7 \pm 1.4 \mathrm{Mg} \mathrm{C}\left(9.9 \pm 0.2 \mathrm{Mg} \mathrm{CO}_{2} \mathrm{eq}\right)$, which corresponds to a carbon sequestration rate of $67 \mathrm{~kg} \mathrm{C} / y e a r\left(245 \mathrm{~kg} \mathrm{CO}_{2} \mathrm{eq} /\right.$ year), which is on the high side for tropical trees reported in the literature. All differences in DBH, height, and biomass were significantly different at $\alpha=0.05$ (unpaired $t$-test on log-transformed values).

Given the freedom to explore the real-world implications of the tree-planting initiative, the students created a wide variety of dissemination "products" in the spirit of a newsworthy piece written in layperson language for the public. Some of the most informative narratives placed the carbon sequestration gains in the context of student's own carbon footprint, vehicle emissions in their city-nation of Singapore, Singapore's carbon footprint, and/or loss of carbon via tropical forest removal (so-called deforestation). Estimates of the carbon lost from tropical deforestation are widespread in a variety of online media and academic/science papers (e.g., Pearson et al. 2017). One student couched the article in terms of the carbon imprint of a family's vacation (Carbon Footprint Ltd. 2020); another in terms of transportation back and forth from school annually.

Again, students were not told how to derive their extended findings, forcing them to use research skills when necessary. However, unlike even a few years ago, there are many online sources to help make these estimates. For example, online carbon footprint calculators, such as those of The Nature Conservancy (2020) are easy to use and provide reasonable estimates. Other online tools allows one to estimate emissions from buildings, car trips, and public transport (e.g., Google Environmental Insights Explorer 2020; International Civil Aviation Organization, The United Nations 2020).

The following passage, which combines findings reported by a few students, demonstrates the learning/contextualization process. The global mean carbon footprint is $5 \mathrm{Mg}$ $\mathrm{CO}_{2}$ /year per person, which is about one-half of the equivalent mass in one rain tree (again $9.9 \pm 0.2 \mathrm{Mg} \mathrm{CO}_{2} \mathrm{eq}$ ). In developed countries, the mean footprint is higher and varies (World Bank 2014): e.g., $\sim 10 \mathrm{Mg} \mathrm{CO}_{2}$ in Singapore; $16.5 \mathrm{Mg} \mathrm{CO}_{2}$ in the USA. Interestingly, the Singapore footprint is roughly that of one mature rain tree. Thus, the $\mathrm{CO}_{2}$ equivalent mass of the 23 rain trees in the green space $\left(231 \mathrm{Mg} \mathrm{CO}_{2}\right.$ eq) accounts for the carbon footprint of approximately 23 years of one's life in Singapore. However, most trees are much smaller than rain trees. If an equivalent mass of $2 \mathrm{Mg} \mathrm{CO}_{2}$ eq is assumed for the average tree, a Singaporean student would need to plant five trees (and leave to maturation) each year to offset their annual carbon footprint. More than 420 trees would then be needed to account for their lifetime footprint (mean life expectancy is 84 years). A student traveling from Singapore to Los Angeles for a vacation would need to plant two trees to offset the $\mathrm{CO}_{2}$ emissions from taking this flight ( $3.9 \mathrm{Mg} \mathrm{CO}_{2}$ emissions). Two and a half trees are roughly equivalent to driving a car $18,000 \mathrm{~km}$ in a year (Government Technology Agency of Singapore 2020).

Many students concluded that climate change mitigation by tree planting alone was, therefore, limited in terms of practicality and scale. The 5.6 million Singaporean residents would need to plant about 28 million "average" trees per year, which is about 40,000 trees per $\mathrm{km}^{2}$, to offset the carbon footprint of the national population. To offset the country's estimated 40 million $\mathrm{Mg}$ of annual $\mathrm{CO}_{2}$ emissions, 20 million new trees would need to be planted each year. In recognizing the impractical nature of such a massive (re) planting, students became aware of the limitation of this solution as a climate change strategy-regardless of the scientific issues. Many then chose to highlight "other" benefits of tree planting, such as increased aesthetics, biodiversity preservation, cooling effects to offset the urban heat island effect, and the potential to trap pollutants. In the end, most students were drawn to paying more close attention to their personal carbon footprints and promoting alternative energy solutions-a result that is inline with both our objective of the exercise, and the goals of sustainability teaching (see "Promoting sustainability education").

\section{Critical discussions}

Here, we point out that the science regarding the true benefit of tree (re)planting on the removal of atmospheric $\mathrm{CO}_{2}$ is debated and still evolving (Green et al. 2019). Nevertheless, the comparisons above helped the students frame a complicated science issue in understandable terms given their various backgrounds. Further, it was the students who made the analogies, not us. Nevertheless, these framings opened the door to further discussions, for example about the trade-offs/feedbacks of planting in different geographical locations (tropics versus temperate/boreal regions); current availability of "deforested" lands (i.e., some are urbanized; others under agriculture); differences between tree-based landscapes and other ecosystems including grasslands; how much of the carbon produced during photosynthesis is transferred to other stores, especially the soil; water use and nutrient demand of trees; the time frame for carbon sequestration; and the fact that tree-planting is not the same as whole ecosystem restoration.

With respect to fieldwork, common observations included reference to: (a) disturbance of rain trees by pruning that creates great biomass variation; (b) difficulty of measuring tree height on uneven ground and for wide canopies that obscured the view of the top of the tree; (c) measurement differences between team members; (d) vastly different canopy shapes for trees of similar height (related to a); and (e) a wide variety of 
tree species of different forms within the "other tree" category for which a common allometric equation was used to estimate biomass. These are common issues flagged by researchers performing similar fieldwork. Thus, the major concerns of the students regarding their calculations revolved around two issues (cf. Vorster et al. 2020): (1) measurement error in the field; and (2) appropriateness of the carbon biomass allometric equations.

With regard to measurement error and uncertainty, many students were concerned about the estimation of $\mathrm{H}$. Tree height measurements are fraught with error because of the difficulty of seeing the location of the top of the tree (Phalla et al. 2018). Thus, there is large uncertainty in the angle from which $\mathrm{H}$ is determined. Further, the measurement is complicated if the ground is not level, which was the case because some of the site was on sloping ground. For some tall trees, estimates from all group members varied by as much as 2 to $4 \mathrm{~m}$. Large errors in $\mathrm{H}$ (up to $25 \%$ for example) produced uncertainties in the biomass estimate that were equivalent to smaller errors in the $\mathrm{D}$ term, which is squared in Eq. 1. Fortunately, the measurement error for D is small, on the order of a few mm. Concerned with the $\mathrm{H}$ term, students, therefore, considered other approaches such as using sophisticated technologies (e.g., LiDAR), triangulation from the top of a building, and using an allometric equation that does not rely on tree height (cf. Phalla et al. 2018).

Concerns were voiced regarding the appropriateness of the two allometric equations (Eqs. 3 and 4) for calculating biomass in the plot. Students questioned their applicability initially because they were developed for tropical trees in general, not for the trees in the plots, specifically (cf. Hunter et al. 2013). For example, one student commented that "When estimating for carbon biomass of urban trees, there tend[s] to be an overestimation-especially if we take streetscapes into account-due to regular pruning”. The student was questioning the accuracy of the estimation from a general allometric relationship that did not account for canopy changes from routine maintenance. However, as Singapore-specific equations do not exist, pantropical equations or ones from similar locales must be used (Yuen et al. 2013). They were also concerned because the determined biomass values were very high compared with other trees in the tropics, including Singapore (Ngo and Lum 2018).

Following these reflections, we introduced the following alternative allometric equations as alternatives to Eqs. 3 and 4, respectively: where Eq. 5 (Chave et al. 2014) does not use height as a variable; and Eq. 6 was determined from individual root systems in a primary dipterocarp forest in Pasoh Forest Reserve, Peninsular Malaysia (Niiyama et al. 2010). Further, Eq. 5 includes the term $E$ that refers to the "health" of the tree stand; it represents factors such as stress from drought, (mis)management, disease, and land degradation.

Incorporation of the two additional equations allowed for other types of analysis:

1. Given a value of $E$ (normally assigned a value of 0.5 ) in Eq. 5, compare the AGCB values computed by Eqs. 3 and 5 ;

2. Compare the BGCB values determined from Eqs. 4 and 6 ;

3. Assuming an accurate and known plot-level AGCB, determine a new value of $\mathrm{E}$ such that Eq. 5 produces a similar value;

4. Perform a sensitivity analysis for all equations to determine how much estimates vary for subtle changes of each input variable $(\mathrm{D}, \mathrm{H}, p)$.

These advanced equations allow students to use various packages to explore the data graphically and perform basic statistical tests such as the paired $t$-test (parametric assumption) or the Wilcoxon ranked sign test (nonparametric assumption). The inclusion of Eq. 5, provided an opportunity for students to implement the advanced Excel Solver function, which is an add-in program that allows one to determine an optimal value by changing variables within one or more equations (e.g., changing E such that the AGB values from Eqs. 3 and 5 have the lowest cumulative/mean difference for all trees). Important in this process is allowing students of all levels to experiment beyond their current repertoire of skills, without being penalized for not being strong in math or computer science.

\section{Informal assessment}

At the end of the semester, we surveyed two separate groups of students using a modified version of the questionnaire of Schroeder et al. (2006). The volunteer online survey questions were emailed to 38 students enrolled in the Test module; 32 , in the Control. We present it here as though it was a formal assessment, but in reality, it was an exercise for us to

$\mathrm{AGB}=\exp \left[-1.803-0.976 \mathrm{E}+0.976 \ln (p)+2.673 \ln (\mathrm{D})-0.0299[\ln (\mathrm{D})]^{2}\right]$

$B G B=0.023 * D^{2.59}$ judge effectiveness to guide future teaching. Nevertheless, we present the outcome here because it demonstrates the positive outcome of the collaborative approach. 
The demographics of the students in the two modules are practically the same in that they were almost equally split in gender and all were Singaporean nationals who were pursuing degrees related to geography or environmental sciences. Few had a strong background in STEM subjects. Given the homogeneity and small size, other demographics were not considered to be important influencing variables in our assessment that was focused on exposure to content. We simply asked the students if "Trees are an effective means of storing carbon". Students were then asked to indicate the extent to which they agreed or disagreed with the following statements regarding the ecosystem services of urban trees:

1. Contributes to your sense of well-being

2. Cools the surrounding environment

3. Improves aesthetics

4. Improves hydrological functioning of the environment

5. Filters aerosols/pollutants from the air

6. Increases wildlife habitats

7. Mitigates climate change by storing carbon

8. Provides shade

9. Reduces noise pollution

Their responses were recorded on a six-point scale, with possible responses ranging from 1 (Strongly disagree) to 6 (Strongly agree). Our main interest was on the responses to statement 7 regarding the role of trees to store carbon and offset the impacts of greenhouse gas (namely $\mathrm{CO}_{2}$ ) emissions to the atmosphere. While the other statements do relate to ecosystem services provided by urban trees, the student views on their role were largely irrelevant to our assessment, but again, provide insight on student exposure to environmental issues. The responses were ranked accordingly to how strongly the students agreed with the statements regarding the role of trees. The critical difference between the two classes was that storing carbon ranked high (3rd) with the Test class, but low (8th) with the Control class who did not do the exercise. We attribute this major difference to the exposure of carbon accounting that the Test class received during the carbon exercise described herein. While we do not claim the results to be a rigorous evaluation, to a certain extent, they were useful to us in evaluating the usefulness of the exercise as an effective mode of conveying information. The ordering of many of the other statements was not surprising, giving the emphasis of urban heat island phenomena, sense of place and natural capital in other modules commonly taken by the students in Singapore.

\section{Promoting sustainability education}

There is growing recognition of the significance of exposing students to sustainability education, which involves introducing the principles, values and practices of sustainable development into all aspects of learning (UNESCO 2005; Helicke 2014). Challenging, however, is presenting an abstract idea such as sustainability in a way that undergraduate students can gain a concrete understanding (Helicke 2014). One strategy in the pursuit of this goal is developing tangible exercises (pedagogical tools) that link the two, merging research ideas and methodologies (Helicke 2014). The carbon measurement exercise represents our attempt to do so in a way that develops a sense of awareness regarding sustainable practices (Sipos et al. 2008).

Conducting the fieldwork portion of the exercise was challenging in that substantial time, administrative support, funding, and planning was needed, as well as preparation of an acceptable risk assessment-all for a brief on-campus activity. However, planning an exercise off-campus, particularly one abroad, is often more challenging. In the current educational environment where universities are re-evaluating the costs and risks of embarking on student field trips, campus-based field exercises offer a means of participating in experiential and high-impact learning activities without venturing beyond the controlled border of the university. This was true even before restrictions on travel were put in place in response to the COVID-19 pandemic. In the context of our Singaporean students, where many have limited experience in non-urban settings, even campus-based activities have tangible value because of the interaction with nature, despite the local urban setting.

Using the NUS landscape as a "classroom" allowed students to perform the underlying measurements and calculations that would give them insight into critiquing the feasibility of tree planting as a viable way to mitigate climate change. It allowed them to participate in an inexact science. It challenged them to question "is this plausible?". In general, students reflecting on the exercise likened the campus green space to a "living laboratory", as is our sentiment. Many students were appreciative for the opportunity to gain experience in fieldwork, as most encountered few other opportunities unless they enrolled in a dedicated module on field studies that is typically taught in the special summer term. For a few students who were not pleased with being forced outdoors in the elements (heat, humidity, sun, insects), the exercise pushed them beyond their normal boundary/comfort zones. Furthermore, the exercise provided a different type of assessment method for which students who are not top-performers in lecture-based settings could potentially excel (although we did not assess this aspect directly).

Most students indicated the experience was positive in the sense that important and relevant questions about the environment could be explored "hands on" and with freedom to interact with fellow students. Most students indicated that the learning experience was "fresh" and "interesting" compared with those from traditional lectures set in a static classroom. A few 
excerpts from student comments give insight into the effectiveness of the exercise. For example, one student commented that "the outdoor activity was really good as we were able to work in teams and share our findings and discuss the measurement errors that we obtained". Another student appreciated the "fieldwork portion and the data collection process" and suggested "similar exercises should be introduced in lower GE [General Education] modules".

By participating in the exercise, it was our hope that students not fully committed to environmental science learning could also see tangible personal benefits, such as a greater sense of environmental awareness that is in concert with shaping future environmental/sustainability attitudes and values. In general, engaging in nature-based learning activities within the campus environs can serve as a springboard that builds momentum towards encouraging an environmental stewardship mentality. Beyond a carbon assessment study, other sustainability initiatives such as rain gardens (biofilters) target water conservation and quality goals. Alternatively, a campus garden/edible landscape can be used to teach organic farming practices and promote a sustainable campus landscape (cf. Krasny and Delia 2015). Contrasting environments involving green and clean spaces on campus create useful locations to measure ground-level air variables related to thermal comfort (related to urban heat island) or ground-level pollution (e.g., dust, ozone, and nitrous oxide).

Because of the potential for using green spaces for teaching, research, conservation and aesthetics, we see value in universities making greater efforts to promote their widespread use (Abdelaal 2019). By promoting positive physical, psychological and cognitive health effects to campus users and the surrounding community (Abdelaal 2019), the biophilic nature of green spaces align with the United Nations Sustainable Development Goals, specifically SDG 4, which aims to promote qualitative education opportunities for all; and it aims to ensure that students acquire the relevant skills and knowledge needed to promote sustainable lifestyles and development by 2030 (United Nations 2015a). In addition, SDG 15 seeks to protect forests and biodiversity; and it aims to ensure the sustainable use of these areas, increase afforestation and reforestation and combat the degradation of natural habitats (United Nations 2015b). The linkage between a real-world activity and sustainability goals is beneficial for students in seeing values in both. This process may be a key factor in motivating and training individuals to work in the areas of terrestrial conservation, climate change and sustainable development.

\section{Providing transferable soft skills}

Finally, an important aspect in most university classes is developing transferable skills. In initial communications with the students, we learned that many have limited knowledge of the realm of skills they acquire throughout their studies, particularly soft/transferable skills. Acquisition of many hard skills is obvious: e.g., map making, spatial analysis, statistical inference, computer programming, operation of laboratory equipment, design and construction of research apparatus, measurement of environmental variables with instrumentation. However, when asked about soft skills, answers were more limited, with some indicating researching, problem solving, teamwork, and communication (Fig. 2). The goal of the carbon assessment exercise was to provide an opportunity to develop both types of skills. The hard skills addressed should be obvious. Thus, we expand on the importance of soft skills below.

Research skills are generally essential to employers because they help the company/organization to rethink/ develop products or services, identify the needs and wants of their customers/stakeholders, evaluate and improve what they do, and keep up with the changes in their industry (Indeed 2020). The research process involves a sequence of interconnected steps: planning, data collection, data collation, data analysis, making informative graphs and tables, creating a data analysis plan, identifying findings, developing conceptual models explaining the results, and producing final written and oral products. Within this process, the ability to recognize and articulate uncertainty is vital to tackling the most complex environmental and sustainability issues of today. For most people, this process is not natural, but something that must be practiced to obtain efficiency (Simpson 2015). Yet, research training can be limited in undergraduate programs, with the exception of final year projects. Thus, basic research experiences can be a foundation in positively influencing student interests in pursuing postgraduate programs or doing effective problem solving in the workforce (Graham et al. 2013; Linn et al. 2015).

The carbon exercise provided the opportunity for the students to practice doing research, thereby allowing them to develop a deeper understanding of the topic and underlying implications revealed by their findings (Seymour et al. 2004). In this sense, research plays an important role in building and rethinking knowledge. We observed some students strengthening their connections between knowledge gained in previous modules and the assignment-particularly students who had taken climate-related modules or math/ computer-based courses. All students were pushed by the nature of the exercise to bolster essential literacy skills, including finding relevant scientific papers containing 
information needed to make calculations and contextualize their findings (Brownell et al. 2015).

Although students are generally very good at locating information via the Internet in this "Google-age", they may not have the base needed to evaluate the information critically, as is needed when solving problems (Salisbury and Karasmanis 2011). Increasingly, employers are looking for students with the ability to join established research teams. Our communications with industry recruiters in Singapore revealed that many anticipate training students on the specific tasks once hired and brought into a team setting where they build upon their knowledge base gained in university or prior work. Thus, we see exercises that practice research on a variety of topics/issues during an undergraduate program being valuable to student development. Ironically, many students believe they need to learn industry-specific tasks in university.

The collaborative approach in the carbon exercise helped foster development of cognitive thinking, reasoning, and decision-making skills (Zittoun et al. 2007). Further, the nature of the exercise enabled students to recognize uncertainties in "science" and re-evaluate the role of a responsible researcher when faced with limitations. Again, part of the challenge revolved around uncertainty in the data because of measurement errors and nature of the allometric equations (see above). Discussions on these issues were a catalyst for students to reflect on the collection and evaluation of data for the assignment, and for problem solving in general (Bruffee 1993). Here, we were particularly trying to push students beyond conceding that a better job could have been done "if only we had access to better equipment". On a positive note, some students did not simply question the appropriateness of the allometric equations, they selected alternative ones as mentioned above.

With regard to teamwork, the students faced some challenges when working with members with different levels of knowledge. Shy, introverted students tended to remain on the side-lines with limited participation, conscientious of making mistakes or having little to add of value. Some students simply do not like group work, especially if they are separated from their friends. In these cases, many students simply followed the consensus of the group. However, our exercise discouraged passiveness, as the students ultimately had to produce an individual final product that built on the group data collection component. On a positive note, students with prior experience with the field techniques often helped the students without prior experience during the data collection. Furthermore, a mentor-mentee relationship was often apparent: students with advanced knowledge in statistics and data analysis guided other group members. In this context, a collaborative transdisciplinary exercise encouraged cognitive knowledge integration but also expanded the development of social interaction among group members (cf. Sweet and Michaelsen 2007). In their reflection, the students revealed positive group interactions and indicated that they enjoyed the opportunities of scientific investigations and discussions within the topics of carbon sequestration, climate change and ecological sustainability. In depth, discussions among students seemed to enhance their curiosity for solving the problem at hand.

With regard to communication, improving environmental literacy and science communication of climate/sustainability action can have wider positive outcomes for the entire university community and lead to a greater appreciation of the natural world. For example, the communication of science through traditional media (newspaper articles) provides opportunities for informal science learning (Maier et al. 2014). While the field exercise gave the students an opportunity to engage in scientific inquiry, the assignment provided an avenue to draw inferences, construct arguments based on the evidence, and communicate the findings simply and effectively. Collectively, these aspects are considered essential literacy skills (Pearson et al. 2010), in light that academics generally need to do "a better job of communicating directly to the public... to communicate the valuable role science plays in the world and to reinforce and enhance positive attitudes toward science and the scientific process"-Ralph Cicerone, President, National Academy of Sciences (2006).

\section{Conclusions}

In this paper, we describe a tangible example of utilizing a university green space as a 'living laboratory' for collaborative learning in addressing an issue of importance to environmental science and sustainability. The integration of campus green spaces as an alternative classroom enabled students to engage a contemporary environmental topic that was close to the hearts of many: the practical effectiveness of a tree-planting initiative in respect to off-setting carbon footprints. Through the data collection/analysis exercise and the written assignment that followed, the students gained an increased awareness of the importance of difficulties in mitigating climate change via carbon management through simple means such as tree planting.

The experience allowed students to develop and/or sharpen important hard and soft skills that are relevant to employment in the environmental and sustainability sector. Specifically, the exercise encouraged collaboration during data collection and analysis, then focused on developing individual communication skills for addressing a general audience. Student-led discussions regarding the efficacy and accuracy of field data collection techniques and equations used to estimate carbon biomass provided students with practice in handling issues related to uncertainty in making scientific assessments. Consequently, the students were 
able to acquire a deeper conceptual understanding regarding topics of carbon sequestration and climate change mitigation than they would attain simply by attending a lecture or through reading (based on discussions with students, but not rigorous assessment).

The estimation of accumulated biomass at the landscapelevel based on plot-inventories is important for many applications, from the commercial exploitation of timber to the global carbon cycle. More and more, these topics are becoming an important curriculum development within environmental sciences. While, the comparisons of the carbon sequestered in trees with real-life phenomena (student carbon footprints) were useful for putting tree-planting schemes into context, we do want to iterate that doing so simplifies complex processes. Nevertheless, these comparisons are made often by media, activists, and policymakers when contextualizing climate change issues and solutions (e.g., Climate Neutral Group 2020). Thus, we feel there is value in exploring such analogies, so long as the issues regarding complexity are also addressed.

Enriching the learning experience was performing the measurements in a green space visible from the window of their classroom. While outdoor field trips are not suited for all academic topics/lessons, where applicable, green spaces within the holistic landscape of a university campus can be commandeered as an effective outdoor learning space. Finally, our case study demonstrates how learning objectives can be amalgamated with a university greening initiative to improve learning. By linking such sustainability initiatives with academic disciplines, educators have more resources to enhance further student engagement and bring about progressive environmental stewardship. Understanding how to perform effective research on current environmental topics can enhance the employability of graduates looking to work within sectors involving sustainability, environmental management, conservation and development.

Acknowledgements We thank Chong Kwek Yan, Jared Moore, Ang Chee Wee and Mahadi bin Sugiri for loaning us several field equipment used in this exercise and for providing tree species list and locations. We also thank the NUS Geography and Bachelor of Environmental Studies students for their participation and candid reflections.

\section{References}

Abdelaal MS (2019) Biophilic campus: an emerging planning approach for a sustainable innovation-conducive university. J Clean Prod 215:1445-1456

Arnfield AJ (2003) Two decades of urban climate research: a review of turbulence, exchanges of energy and water, and the urban heat island. Int J Climatol 23:1-26. https://doi.org/10.1002/joc.859

Banaticla MR, Sales R, Lasco R (2007) Biomass equations for tropical tree plantation species in young stands using secondary data from the Philippines. Ann Trop Res. https://doi.org/10.32945/ atr2937.2007

Bastin J-F, Finegold Y, Garcia C et al (2019) The global tree restoration potential. Science 365:76-79. https://doi.org/10.1126/scien ce.aax0848

Blackmore J, Bateman D, Loughlin J, O’Mara J (2011) Research into the connection between built learning spaces and student outcomes

Blumstein DT, Saylan C (2007) The failure of environmental education (and How We Can Fix It). PLoS Biol. https://doi.org/10.1371/ journal.pbio.0050120

Bonwell CC, Sutherland TE (1996) The active learning continuum: Choosing activities to engage students in the classroom. New Dir Teach Learn 1996:3-16. https://doi.org/10.1002/tl.37219966704

Braubach M, Egorov A, Mudu P et al (2017) Effects of urban green space on environmental health equity and resilience. In: Kabisch N., Korn H., Stadler J., Bonn A. (Eds.) Nature-based solutions to climate change adaptation in urban areas. Theory and practice of urban sustainability transitions. Springer, Cham, pp 187-205

Brown JH, Gillooly JF, Allen AP et al (2004) Toward a metabolic theory of ecology. Ecology 85:1771-1789. https://doi. org/10.1890/03-9000

Brown S (1997) Estimating biomass and biomass change of tropical forests: A primer. FAO Forestry Paper - 134. FAO FORESTRY PAPER, Rome

Brown S (2002) Measuring carbon in forests: Current status and future challenges. Environ Pollut 116:363-372. https://doi.org/10.1016/ S0269-7491(01)00212-3

Brownell SE, Hekmat-Scafe DS, Singla V et al (2015) A high-enrollment course-based undergraduate research experience improves student conceptions of scientific thinking and ability to interpret data. CBE-Life Sci Educ 14:21. https://doi.org/10.1187/ cbe.14-05-0092

Bruffee KA (1993) Collaborative learning: Higher education, interdependence, and the authority of knowledge. Johns Hopkins University Press, Baltimore

Brundtland GH (1987) Report of the world commission on environment and development: Our common future. World Commission on Environment and Development, Oxford

Burns HL (2015) Transformative sustainability pedagogy: Learning from ecological systems and indigenous wisdom. J Transform Educ. https://doi.org/10.1177/1541344615584683

Byers T, Imms W, Hartnell-Young E (2014) Making the case for space: the effect of learning spaces on teaching and learning. Curric Teach 29:5-19. https://doi.org/10.7459/ct/29.1.02

Carbon Footprint Ltd. https://www.carbonfootprint.com/calculator .aspx. Accessed 20 Nov 2020

Chan N, Takeda S, Suzuki R, Yamamoto S (2013) Establishment of allometric models and estimation of biomass recovery of swidden cultivation fallows in mixed deciduous forests of the Bago Mountains, Myanmar. For Ecol Manage 304:427-436. https:// doi.org/10.1016/j.foreco.2013.05.038

Chave J, Réjou-Méchain M, Búrquez A et al (2014) Improved allometric models to estimate the aboveground biomass of tropical trees. Glob Chang Biol 20:3177-3190. https://doi.org/10.1111/ gcb. 12629

Chazdon R, Brancalion P (2019) Restoring forests as a means to many ends. Science 365:24-25. https://doi.org/10.1126/science.aax95 39

Chen G, Ozelkan E, Singh KK et al (2017) Uncertainties in mapping forest carbon in urban ecosystems. J Environ Manage 187:229238. https://doi.org/10.1016/j.jenvman.2016.11.062

Chow WTL, Akbar SNABA, Heng SL, Roth M (2016) Assessment of measured and perceived microclimates within a tropical urban forest. Urban For Urban Green 16:62-75. https://doi. org/10.1016/j.ufug.2016.01.010 
City of London Trees and Woodlands. https://www.london.gov.uk/ what-we-do/environment/parks-green-spaces-and-biodiversity/ trees-and-woodlands. Accessed 25 May 2020

City of New York (2011) Million Trees NYC. https://www.milliontre esnyc.org/. Accessed 25 May 2020

Clark DB, Kellner JR (2012) Tropical forest biomass estimation and the fallacy of misplaced concreteness. J Veg Sci 23:1191-1196. https://doi.org/10.1111/j.1654-1103.2012.01471.x

Climate Neutral Group What exactly is 1 tonne of $\mathrm{CO}_{2}$ ? https://www. climateneutralgroup.com/en/news/what-exactly-is-1-tonne-ofco2/. Accessed 24 Nov 2020

Cunia T (1987) An optimization model for subsampling trees for biomass measurement. In: Wharton EH, Cunia T (Eds.) Estimating tree biomass regressions and their error. Department of Agriculture Forest Service, Broomall, pp 27-36

Cushman KC, Muller-Landau HC, Condit RS, Hubbell SP (2014) Improving estimates of biomass change in buttressed trees using tree taper models. Methods Ecol Evol 5:573-582. https://doi. org/10.1111/2041-210X.12187

Duerdoth I (2009) Teaching uncertainties. Phys Educ 44:138-144. https://doi.org/10.1088/0031-9120/44/2/004

DuPuis EM, Ball T (2013) How not what: Teaching sustainability as process. Sustain Sci Pract Policy. https://doi.org/10.1080/15487 733.2013.11908108

European Environment Agency (2012) Trees help tackle climate change. https://www.eea.europa.eu/articles/forests-health-andclimate-change/key-facts/trees-help-tackle-climate-change. Accessed 25 May 2020

Fisher JI, Hurtt GC, Thomas RQ, Chambers JQ (2008) Clustered disturbances lead to bias in large-scale estimates based on forest sample plots. Ecol Lett 11:554-563. https://doi.org/10.111 $1 / \mathrm{j} .1461-0248.2008 .01169 . x$

Frangoul A (2020) How the mass planting of trees could transform our cities and tackle air pollution. Business News, Sustainable Energy. https://www.cnbc.com/2020/04/17/how-the-mass-plant ing-of-trees-could-transform-our-cities.html. Accessed 15 May 2020

Fuller IC (2006) What is the value of fieldwork? Answers from New Zealand using two contrasting undergraduate physical geography field trips. N Z Geog 62:215-220. https://doi.org/10.111 1/j.1745-7939.2006.00072.x

Fuller RA, Irvine KN, Devine-Wright P et al (2007) Psychological benefits of greenspace increase with biodiversity. Biol Lett 3:390-394. https://doi.org/10.1098/rsbl.2007.0149

Gehrt SD, Chelsvig JE (2004) Species-specific patterns of bat activity in an urban landscape. Ecol Appl 14:625-635. https://doi. org/10.1890/03-5013

Gokhale AA (1995) Collaborative learning enhances critical thinking. J Technol Educ 7:22-30. https://doi.org/10.21061/jte.v7i1.a.2

Google Environmental Insights Explorer https://insights.sustainability. google/. Accessed 28 May 2020

Government Technology Agency of Singapore. https://data.gov.sg/. Accessed 28 May 2020

Graham MJ, Frederick J, Byars-Winston A et al (2013) Increasing persistence of college students in STEM. Science 341:1455-1456. https://doi.org/10.1126/science.1240487

Green JK, Seneviratne SI, Berg AM et al (2019) Large influence of soil moisture on long-term terrestrial carbon uptake. Nature 565:476479. https://doi.org/10.1038/s41586-018-0848-x

Helicke NA (2014) Learning and promoting urban sustainability: Environmental service learning in an undergraduate environmental studies curriculum. J Environ Stud Sci 4:294-300. https://doi. org/10.1007/s13412-014-0194-8

Heryati Y, Belawan D, Abdu A et al (2011) Growth performance and biomass accumulation of a Khaya ivorensis plantation in three soil series of Ultisols. Am J Agric Biol Sci 6:33-44. https://doi. org/10.3844/ajabssp.2011.33.44

Holl KD, Brancalion PHS (2020) Tree planting is not a simple solution. Science 368:580-581. https://doi.org/10.1126/science.aba8232

Hunter MO, Keller M, Victoria D, Morton DC (2013) Tree height and tropical forest biomass estimation. Biogeosciences 10:83858399. https://doi.org/10.5194/bg-10-8385-2013

Huxley J (1932) Problems of relative growth. The Dial Press, New York

Indeed (2020) Research Skills: Definition and Examples. https://www. indeed.com/career-advice/career-development/research-skills. Accessed 30 May 2020

International Civil Aviation Organization The United Nations. https ://www.icao.int/environmental-protection/Carbonoffset/Pages /default.aspx. Accessed 28 May 2020

IPCC (2006) IPCC guidelines for national greenhouse gas inventories. Intergovernmental Panel on Climate Change, Hayama

IPCC (2003) Good practice guidance for land-use change and forestry. IPCC/OECD/IEA/IGES, Hayama

Jim CY, Chen WY (2008) Assessing the ecosystem service of air pollutant removal by urban trees in Guangzhou (China). J Environ Manage 88:665-676. https://doi.org/10.1016/j.jenvm an.2007.03.035

Jones P, Selby D, Sterling SR (2010) Sustainability education: Perspectives and practice across higher education. Earthscan, Washington, DC

Kahan DM, Jenkins-Smith H, Braman D (2011) Cultural cognition of scientific consensus. J Risk Res 14:147-174. https://doi. org/10.1080/13669877.2010.511246

Kellert S, Calabrese E (2015) The Practice of Biophilic Design www.biophilic-design.com. Accessed 18 May 2020

Krasny ME, Delia J (2015) Natural area stewardship as part of campus sustainability. J Clean Prod 106:87-96. https://doi. org/10.1016/j.jclepro.2014.04.019

Laurance WF, Fearnside PM, Laurance SG et al (1999) Relationship between soils and Amazon forest biomass: A landscape-scale study. For Ecol Manage 118:127-138. https://doi.org/10.1016/ S0378-1127(98)00494-0

Lewis SL, Wheeler CE, Mitchard ETA, Koch A (2019) Restoring natural forests is the best way to remove atmospheric carbon. Nature 568:25-28. https://doi.org/10.1038/d41586-019-01026 $-8$

Linn MC, Palmer E, Baranger A et al (2015) Undergraduate research experiences: Impacts and opportunities. Science 347:1261757. https://doi.org/10.1126/science.1261757

Maier M, Rothmund T, Retzbach A et al (2014) Informal learning through science media usage. Educ Psychol 49:86-103. https:// doi.org/10.1080/00461520.2014.916215

Martins AA, Mata TM, Costa CAV (2006) Education for sustainability: Challenges and trends. Clean Technol Environ Policy 8:31-37. https://doi.org/10.1007/s10098-005-0026-3

Matthews G (1993) The carbon content of trees. Forestry Commission Technical Paper

Monahan T (2002) Flexible space and built pedagogy: Emerging IT embodiments. Inventio 4:1-19

Muller-Landau HC, Detto M, Chisholm RA et al (2014) Detecting and projecting changes in forest biomass from plot data. In: Coomes DA, Burslem DFR, Simonson WD (Eds.) Forests and global change. Cambridge University Press, Cambridge, pp 381-415

National Parks Board NParks to work with the community to transform Singapore into a City in Nature. https://www.nparks.gov.sg/ news/2020/3/nparks-to-work-with-the-community-to-transformsingapore-into-a-city-in-nature. Accessed 18 May 2020

National University of Singapore (2018) NUS News. http://news.nus. edu.sg/highlights/greening-our-campus. Accessed 15 May 2020 
Newman P (2014) Biophilic urbanism: A case study on Singapore. Aust Plan 51:47-65. https://doi.org/10.1080/07293682.2013.790832

Ngo KM, Lum S (2018) Aboveground biomass estimation of tropical street trees. J Urban Ecol. https://doi.org/10.1093/jue/jux020

Niiyama K, Kajimoto T, Matsuura Y et al (2010) Estimation of root biomass based on excavation of individual root systems in a primary dipterocarp forest in Pasoh Forest Reserve, Peninsular Malaysia. J Trop Ecol 26:271-284. https://doi.org/10.1017/ S0266467410000040

Oblinger D (2005) Leading the transition from classrooms to learning spaces. Society for College and University Planning, Ann Arbor

Painter S, Fournier J, Grape C, et al (2013) Research on Learning Space Design: Present State, Future Directions

Pan Y, Birdsey RA, Fang J, et al (2011) A large and persistent carbon sink in the world's forests. Science 333:988-993. https://doi. org/10.1126/science.1201609

Pandey M (2019) Climate change: What is being done around the world to plant trees? https://www.bbc.com/news/newsbeat-48884165. Accessed 26 Jul 2020

Patt A (2007) Assessing model-based and conflict-based uncertainty. Glob Environ Chang 17:37-46. https://doi.org/10.1016/j.gloen vcha.2006.10.002

Pearson PD, Moje E, Greenleaf C (2010) Literacy and science: Each in the service of the other. Science 328:459-463. https://doi. org/10.1126/science.1182595

Pearson TRH, Brown S, Murray L, Sidman G (2017) Greenhouse gas emissions from tropical forest degradation: An underestimated source. Carbon Balance Manag. 12:3-13. https://doi. org/10.1186/s13021-017-0072-2

Petersson H, Holm S, Ståhl G et al (2012) Individual tree biomass equations or biomass expansion factors for assessment of carbon stock changes in living biomass-A comparative study. For Ecol Manage 270:78-84. https://doi.org/10.1016/j.foreco.2012.01.004

Phalla T, Ota T, Mizoue N et al (2018) The importance of tree height in estimating individual tree biomass while considering errors in measurements and allometric models. AGRIVITA J Agric Sci 40:131-140. https://doi.org/10.17503/agrivita.v40i1.1730

Popkin G (2019) The forest question. Nature 565:280-282

Raza A, Gholami R, Rezaee R et al (2019) Significant aspects of carbon capture and storage-A review. Petroleum 5:335-340. https:// doi.org/10.1016/j.petlm.2018.12.007

Robinson Z (2011) Teaching climate change in higher education: Barriers and opportunities. In: Heslett SK, France D, Gedye S (Eds.) Pedagogy of climate change. Higher Education Academy, Geography, Earth, and Environmental, Sciences, London, pp 36-50

Roxburgh SH, Paul KI, Clifford D et al (2015) Guidelines for constructing allometric models for the prediction of woody biomass: How many individuals to harvest? Ecosphere 6:1-27. https://doi. org/10.1890/ES14-00251.1

Salisbury F, Karasmanis S (2011) Are they ready? Exploring student information literacy skills in the transition from secondary to tertiary education. Aust Acad Res Libr 42:43-58. https://doi. org/10.1080/00048623.2011.10722203

Schellens T, Valcke M (2006) Fostering knowledge construction in university students through asynchronous discussion groups. Comput Educ 46:349-370. https://doi.org/10.1016/j.compe du.2004.07.010

Scholl KG, Gulwadi GB (2015) Recognizing campus landscapes as learning spaces. J Learn Spaces 4:53-60

Schroeder H, Flannigan J, Coles R (2006) Residents' attitudes toward street trees in the UK and U.S. Communities Arboric Urban For 32:236-246

Seymour E, Hunter A-B, Laursen SL, DeAntoni T (2004) Establishing the benefits of research experiences for undergraduates in the sciences: First findings from a three-year study. Sci Educ 88:493-534. https://doi.org/10.1002/sce.10131
Shi L, Liu S (2017) Methods of Estimating Forest Biomass: A Review. In: Biomass Volume Estimation and Valorization for Energy

Sileshi GW (2014) A critical review of forest biomass estimation models, common mistakes and corrective measures. For Ecol Manage 329:237-254. https://doi.org/10.1016/j.foreco.2014.06.026

Simpson SH (2015) Creating a data analysis plan: What to consider when choosing statistics for a study. Can J Hosp Pharm 68:311317. https://doi.org/10.4212/cjhp.v68i4.1471

Sipos Y, Battisti B, Grimm K (2008) Achieving transformative sustainability learning: Engaging head, hands and heart. Int J Sustain High Educ 9:68-86. https://doi.org/10.1108/146763708108421 93

Sweet M, Michaelsen LK (2007) How group dynamics research can inform the theory and practice of postsecondary small group learning. Educ Psychol Rev 19:31-47. https://doi.org/10.1007/ s10648-006-9035-y

The Nature Conservancy https://www.nature.org/en-us/get-involved/ how-to-help/carbon-footprint-calculator/. Accessed 28 May 2020

Trlica A, Hutyra LR, Morreale LL et al (2020) Current and future biomass carbon uptake in Boston's urban forest. Sci Total Environ 709:136196. https://doi.org/10.1016/j.scitotenv.2019.136196

UNESCO (2005) Contributing to a more sustainable future: Quality education, life skills and education for sustainable development. ED/PEQ/IQL/2005/PI/H/2. Paris

United Nations (2015a) Sustainable Development Goals Knowledge Platform - SDG 4. https://sustainabledevelopment.un.org/sdg4. Accessed 25 May 2020

United Nations (2015b) Sustainable Development Goals Knowledge Platform - SDG 15. https://sustainabledevelopment.un.org/sdg15. Accessed 25 May 2020

Vorster AG, Evangelista PH, Stovall AEL, Ex S (2020) Variability and uncertainty in forest biomass estimates from the tree to landscape scale: The role of allometric equations. Carbon Balance Manag. https://doi.org/10.1186/s13021-020-00143-6

Way T, Matthews C, Rottle N, Toland TR (2012) Greening the American campus: Lessons from campus projects. Plan High Educ 40:25-47

Whitford V (2001) "City form and natural process" - Indicators for the ecological performance of urban areas and their application. Landsc Urban Plan 57:91-103. https://doi.org/10.1016/S0169 -2046(01)00192-X

Whitmarsh L (2011) Scepticism and uncertainty about climate change: Dimensions, determinants and change over time. Glob Environ Chang 21:690-700. https://doi.org/10.1016/j.gloen vcha.2011.01.016

Wolsink M (2016) Environmental education excursions and proximity to urban green space-Densification in a 'compact city.' Environ Educ Res 22:1049-1071. https://doi.org/10.1080/13504 622.2015 .1077504

Wong NH, Chen Y (2008) Tropical urban heat islands: Climate, Buildings and Greenery. London, Routledge, p 19

World Bank (2014) $\mathrm{CO}_{2}$ emissions (metric tons per capita). https:// data.worldbank.org/indicator/EN.ATM.CO2E.PC?most_recen t_year_desc $=$ true. Accessed 25 May 2020

Yarnal B, Neff R (2007) Teaching global change in local places: The HERO research experiences for undergraduates program. J Geogr High Educ 31:413-426. https://doi.org/10.1080/0309826060 1082339

Yuen JQ, Fung T, Ziegler AD (2016) Review of allometric equations for major land covers in SE Asia: Uncertainty and implications for above- and below-ground carbon estimates. For Ecol Manage 360:323-340. https://doi.org/10.1016/J.FORECO.2015.09.016

Yuen JQ, Ziegler AD, Webb EL, Ryan CM (2013) Uncertainty in below-ground carbon biomass for major land covers in Southeast Asia. For Ecol Manage 310:915-926. https://doi.org/10.1016/j. foreco.2013.09.042 
Ziegler AD, Echaubard P, Lee YT et al (2016) Untangling the complexity of liver fluke infection and cholangiocarcinoma in NE Thailand through transdisciplinary learning. EcoHealth 13:316-327. https://doi.org/10.1007/s10393-015-1087-3

Zittoun T, Baucal A, Cornish F, Gillespie A (2007) Collaborative research, knowledge and emergence. Integr Psychol Behav Sci 41:208-217. https://doi.org/10.1007/s12124-007-9021-z
Publisher's Note Springer Nature remains neutral with regard to jurisdictional claims in published maps and institutional affiliations. 